\title{
PERBUATAN MELAWAN HUKUM OLEH HOTEL TERKAIT MENJALANKAN USAHA PAKET WISATA PERJALANAN DI BALI
}

\section{Petrus Stefano Roberto Makawangkel Ika Dewi Sartika Saimima}

\begin{abstract}
Abstrak
Dalam menunjang kepariwisataan Bali, hotel sebagai usaha sarana pariwisata di bidang penyediaan akomodasi tentunya menjadi faktor penunjang yang sangat penting. Namun dari data yang diperoleh Dinas Pariwisata Provinsi Bali, tingkat hunian hotel berbintang dari tahun 2013 sampai 2017 tidak mengalami kenaikan yang menggembirakan, bahkan cenderung stagnan. Hal tersebut menyebabkan munculnya inovasi yang "kebablasan" yang berakibat pada persaingan tidak sehat antara hotel dengan Biro Perjalanan Wisata. Banyak hotel menjalankan paket perjalanan wisata yang lazim menjadi "market" Biro Perjalanan Wisata. Padahal hotel sudah jelas porsinya, yang berhak jual paket tour itu adalah Biro Perjalanan Wisata. Hal ini dapat mengakibatkan kerugian bagi pihak Biro Perjalanan Wisata, dan yang lebih bahaya lagi jika di biarkan terus terjadi maka dapat menimbulkan ketidakseimbangan iklim usaha pariwisata yang dapat mengakibatkan terjadinya " tourism kills tourism". Hotel yang menjalankan paket perjalanan wisata secara langsung maupun tidak langsung merebut dan mengurangi "market" bagi pelaku usaha Biro Perjalanan Wisata sehingga mengakibatkan kerugian baik materiil maupun immaterial dan perbuatan pihak hotel tersebut merupakan pelanggaran hukum yang berlaku. Kejadian ini merupakan peristiwa hukum yang terkait Perbuatan Melawan Hukum oleh pihak hotel karena menjalankan usaha paket perjalanan wisata yang seharusnya menjadi lingkup usaha pihak Biro Perjalanan Wisata. Dimana masalah ini dapat diselesaikan melalui jalur hukum berupa gugatan perdata oleh pihak yang dirugikan, dalam hal ini pihak Biro Perjalanan Wisata atas Perbuatan Melawan Hukum yang berdampak kerugian, yang dilakukan oleh pihak hotel.

Kata- kata Kunci : Perbuatan melawan hukum, biro perjalanan wisata, perhotelan, persaingan usaha tidak sehat.
\end{abstract}




\section{PENDAHULUAN.}

Pulau Bali yang juga dikenal sebagai pulau Dewata, menjadi gerbang utama pariwisata di Indonesia karena memiliki berbagai potensi pariwisata andalan, mulai dari potensi sumber daya alam, potensi kesenian, religi serta akar sejarah kearifan lokal yang mengemuka dalam budaya kehidupan masyarakat Bali sehingga dapat terwujud hubungan timbal balik yang dinamis, harmonis dan sinergis antara kepariwisataan dan kebudayaan. Hal tersebut tercermin dalam kegiatan masyarakat Bali sehari-hari yang menjunjung tinggi falsafah hidup Tri Hita Karana, yang memuat tiga unsur yang membangun keseimbangan dan keharmonisan hubungan antara manusia dengan Tuhan, manusia dengan manusia, dan manusia dengan lingkungannya yang menjadi sumber kesejahteraan, kedamaian dan kebahagiaan bagi kehidupan manusia. ${ }^{1}$ Dengan Tri Hita Karana sebagai falsafah/filsafat kehidupan serta etika moral, masyarakat Bali diharapkan dapat mengembangkan kehidupan Kepariwisataan sambil terus melestarikan kebudayaan dan sumber daya lingkungan alamnya ditengah modernisasi, globalisasi serta homogenisasi yang terjadi saat ini.

Dalam sektor industri pariwisata, Pemerintah Provinsi Bali terus melakukan berbagai upaya untuk meperbaiki serta mengembangkan pariwisata di Bali guna mendukung target 20 juta wisatawan mancanegara pada tahun 2019. Semua inovasi daya tarik pariwisata dilakukan dengan mengedepankan kebutuhan wisatawan yaitu kenyamanan, keamanan, dan aksesibilitas dengan tanpa meninggalkan kearifan lokal budaya masyarakat Bali.

Untuk mengakomodir perkembangan kunjungan wisatawan, berbagai sarana penunjang seperti misalnya restoran, "art shop", pasar seni, sarana hiburan, destinasi wisata tumbuh dengan pesat yang kemudian muncul pula kebutuhan terbentuknya organisasi yang mewadahi usaha -usaha kepariwisataan seperti PHRI (Perhimpunan Hotel dan Restoran Indonesia), ASITA (Asosiasi Perusahaan Perjalanan Wisata Indonesia/ Association of the Indonesian Tours and Travel Agencies), dan lembaga kepariwisataan lain di Bali, yang secara profesional mengelola dan memberi layanan jasa pariwisata, serta memberi jaminan untuk kenyamanan berwisata di Bali. Tiap organisasi bekerja dalam lingkup kegiatan usaha yang di wakilinya dengan tujuan agar tercapai keseimbangan antara golongan usaha pariwisata yang satu dengan lainnya.

Dalam menunjang kepariwisataan Bali, hotel sebagai usaha sarana pariwisata di bidang penyediaan akomodasi tentunya menjadi faktor penunjang yang sangat penting. Banyak sekali kontribusi industri perhotelan yang berimplikasi langsung bagi perkembangan pariwisata di Bali. Semakin banyak wisatawan yang akan berkunjung tentunya semakin banyak pula kebutuhan akan

\footnotetext{
${ }^{1}$ Yayasan Bai Galang, http://www.babadbali.com/canangsari/trihitakarana.htm, diakses 14 Februari 2018, pukul. 20.00 wib. Lihat ketentuan umum, Pasal 1 peraturan daerah provinsi Bali nomor 2 tahun 2012 tentang kepariwisataan budaya Bali, diakses 15 Februari 2018, pukul 15.00. wib.
} 
penyediaan akomodasi seperti hotel, losmen. Oleh karena itu dari sisi ekonomi, hubungan industri perhotelan dengan kepariwisataan sangatlah erat dimana dapat dilihat semakin tinggi jumlah wisatawan yang berkunjung, menginap dan tinggal semakin lama, maka semakin banyak wisatawan tersebut belanja di suatu daerah wisata sehingga hal ini berdampak langsung bagi pendapatan daerah dan kegiatan ekonomi masyarakat di daerah tersebut. Dari sisi sosiologis, semakin banyak wisatawan yang datang ke daerah tersebut maka masyarakat dan pemerintah daerah tersebut akan semakin berbenah diri agar dapat menyambut wisatawan.

\section{Tabel 1.}

PROSENTASE TINGKAT HUNIAN KAMAR HOTEL DI BALI $2012-2017^{2}$

\begin{tabular}{|c|l|l|l|l|l|}
\hline BULAN & 013 & 014 & $015^{*}$ & 016 & $017 *$ \\
\hline \multirow{2}{*}{ Januari } & 7.57 & 7.76 & 6.11 & 4.38 & 9.61 \\
& $\%$ & $\%$ & $\%$ & $\%$ & $\%$ \\
\hline Februari & 8.05 & 9.13 & 8.45 & 2.46 & 0.82 \\
& $\%$ & $\%$ & $\%$ & $\%$ & $\%$ \\
\hline Maret & 0.12 & 9.87 & 4.68 & 8.56 & 6.58 \\
\hline April & $\%$ & $\%$ & $\%$ & $\%$ & $\%$ \\
\hline Juni & 1.05 & 2.10 & 8.52 & 6.77 & 6.72 \\
& $\%$ & $\%$ & $\%$ & $\%$ & $\%$ \\
\hline Mei & 0.31 & 1.01 & 6.31 & 0.04 & 1.91 \\
& $\%$ & $\%$ & $\%$ & $\%$ & $\%$ \\
\hline & $\%$ & $\%$ & 5.08 & 8.54 \\
\hline
\end{tabular}

\footnotetext{
${ }^{2}$ Prosentase tingkat hunian kamar hotel di Bali Th.2012-2017,http://www.disparda.baliprov.go.id/id/Statistik4, diakses 17 Februari 2018, pukul 15.30. wib.
} 


\begin{tabular}{|c|c|c|c|c|c|}
\hline & $\begin{array}{l}2.44 \\
\%\end{array}$ & $\begin{array}{l}1.40 \\
\%\end{array}$ & $\begin{array}{l}8.54 \\
\%\end{array}$ & $\begin{array}{l}0.62 \\
\%\end{array}$ & $\begin{array}{l}2.32 \\
\%\end{array}$ \\
\hline Agustus & $\begin{array}{l}2.64 \\
\%\end{array}$ & $\begin{array}{l}2.07 \\
\%\end{array}$ & $\begin{array}{l}9.61 \\
\%\end{array}$ & $\begin{array}{l}2.40 \\
\%\end{array}$ & $\begin{array}{l}4.86 \\
\%\end{array}$ \\
\hline September & $\begin{array}{l}3.76 \\
\%\end{array}$ & $\begin{array}{l}3.87 \\
\%\end{array}$ & $\begin{array}{l}0.30 \\
\%\end{array}$ & $\begin{array}{l}8.26 \\
\%\end{array}$ & $\begin{array}{l}2.64 \\
\%\end{array}$ \\
\hline Oktober & $\begin{array}{l}0.57 \\
\%\end{array}$ & $\begin{array}{l}2.83 \\
\%\end{array}$ & $\begin{array}{l}5.45 \\
\%\end{array}$ & $\begin{array}{l}2.19 \\
\%\end{array}$ & $\begin{array}{l}5.93 \\
\%\end{array}$ \\
\hline November & $\begin{array}{l}0.94 \\
\%\end{array}$ & $\begin{array}{l}1.36 \\
\%\end{array}$ & $\begin{array}{l}9.09 \\
\%\end{array}$ & $\begin{array}{l}9.71 \\
\%\end{array}$ & $\begin{array}{l}4.08 \\
\%\end{array}$ \\
\hline Desember & $\begin{array}{l}2.53 \\
\%\end{array}$ & $\begin{array}{l}1.07 \\
\%\end{array}$ & $\begin{array}{l}0.32 \\
\%\end{array}$ & $\begin{array}{l}0.08 \\
\%\end{array}$ & $\begin{array}{l}0.66 \\
\%\end{array}$ \\
\hline RATA2 & $\begin{array}{l}3.21 \\
\%\end{array}$ & $\begin{array}{l}0.31 \\
\%\end{array}$ & $\begin{array}{l}8.14 \\
\%\end{array}$ & $\begin{array}{l}1.71 \\
\%\end{array}$ & $\begin{array}{l}2.89 \\
\%\end{array}$ \\
\hline
\end{tabular}

Sumber : disparda.baliprov.go.id, 2018

Dalam melakukan pembinaan penyelenggaraan kepariwisataan, pemerintah terus melakukan riset terkait daya tampung dan "berapa sebenarnya" pulau Bali membutuhkan hotel agar seimbang antara supply dan demand serta tidak terjadi kelebihan kapasitas pembangunan hotel di Bali yang dapat menyebabkan munculnya persaingan tidak sehat baik antar hotel maupun antara industri perhotelan dengan industri pariwisata lainnya. Oleh karena itu diperlukan adanya aturan, pengawasan serta kebijakan-kebijakan yang membuat semua element kepariwisataan dapat berjalan sinergis.

Sebagai salah satu usaha sarana pariwisata, industri perhotelan terus melakukan inovasi produk yang ditawarkan kepada calon wisatawan agar jumlah wisatawan yang datang tidak berkurang bahkan terus bertambah. Namun dari data yang diperoleh Dinas Pariwisata Provinsi Bali, tingkat hunian hotel berbintang dari tahun 2013 sampai 2017 tidak mengalami kenaikan yang 
menggembirakan, bahkan cenderung stagnan. Kondisi ini bukan hanya karena mengenai jumlah wisatawan yang datang, melainkan juga karena jumlah hotel di Bali yang terus meningkat sehingga mempengaruhi jumlah okupansi hotel. Hal ini tercermin pada data yang diperoleh dari website resmi Dinas Pariwisata Daerah Provinsi Bali, sebagai berikut.

"Ketua Perhimpunan Hotel dan Restoran Indonesia (PHRI) Provinsi Bali Tjokorda Oka Artha Ardhana Sukawati menilai jumlah hotel di Pulau Dewata sudah melebihi kapasitas yang tidak diimbangi dengan banyaknya tingkat hunian (okupansi) yang terisi oleh wisatawan". ${ }^{3}$

Dugaan akan perkembangan jumlah hotel yang tidak seimbang ini semakin kuat sesuai keterangan yang di sampaikan oleh Dr. Ir. Agung Suryawan Wiranatha, MSc, dari Aliansi Tokoh Masyarakat Bali (ATMB) dalam pers rilisnya pada tanggal 30 Maret 2016 sebagai berikut:

"Pertumbuhan kunjungan wisatawan mancanegara sebesar 15\% per tahun selama kurun waktu satu dekade terakhir inilah yang menyebabkan ketertarikan para investor untuk menanamkan modalnya di sektor pariwisata di Bali. Namun, pilihan investor tersebut sebagian besar pada subsektor akomodasi pariwisata. Hal ini dapat dipahami karena, sub-sektor akomodasi pariwisata menerima sekitar 35\% dari seluruh pengeluaran wisatawan mancanegara selama mereka berada di Bali. Jumlah akomodasi pariwisata yang terdata oleh PHRI Bali pada akhir tahun 2015 ini sekitar 130.000 kamar. Jumlah yang sangat jauh berbeda dengan data resmi dari Diparda Bali pada tahun 2014 sebanyak 61.000 kamar.

Ada apa dengan data akomodasi pariwisata di Bali ini ? Diperkirakan banyak akomodasi parwisata yang beroperasi secara ilegal. Kepariwisataan Bali mengalami perkembangan yang sangat pesat dalam satu dekade terakhhir ini, bahkan dapat dikatakan perkembangannya kurang terkontrol oleh pihak berwenang. Perkembangan yang sangat pesat ini dipicu oleh pertumbuhan kedatangan wisatawan mancanegara ke Bali yang rata-rata sekitar 15\% per tahun. Dimana pada tahun 2015 yang lalu, Bali menerima kunjungan lebih dari 4 juta wisatawan mancanegara yang datang langsung ke Bali ( Foreign Visitor Direct Arrivals ). " “.

Data tersebut menggambarkan munculnya persaingan tidak sehat antar pelaku usaha perhotelan itu sendiri, sementara seiring perkembangan strategi dan inovasi-inovasi untuk memenuhi kebutuhan tingkat hunian hotel yang ada, fungsi hotel sebagai "Usaha Sarana Pariwisata Penyediaan Akomodasi", berkembang menjadi tempat seminar, pertemuan bisnis, pesta pernikahan, lokakarya

\footnotetext{
${ }^{3}$ I Made Surya, PHRI : Jumlah hotel di Bali membludak,Shttps://bali.antaranews.com/berita/102794/phri-jumlah-hoteldi-bali-membludak, diakses 17 Februari 2018, pukul. 20.15 wib. ${ }^{4}$ https://beritabali.com/read/2016/03/30/201603300001/Pariwisata-Bali-Tak-Terkontrol-Akan-Terjadi-Tourism-Kills-
Tourism.html, diakses 17 Februari 2018, pukul. 20.30 wib.
} 
bahkan tempat berbagai kegiatan lembaga-lembaga pemerintahan maupun non pemerintahan. Dengan sarana dan prasarana yang dimiliki, Hotel menjadi semacam "One Stop Centre" untuk melakukan berbagai kegiatan yang ingin dilakukan oleh para tamu.

Hal tersebut menyebabkan munculnya persaingan usaha yang tidak sehat, baik antar hotel maupun antara industri perhotelan dengan industri pariwisata lainnya, karena selain industri perhotelan, dunia kepariwisataan memiliki banyak aspek yang mencakup pengaturan pergerakan wisatawan dari lokasi asal dan di daerah tujuan wisata dengan berbagai kebutuhan wisatawan yang melibatkan banyak jenis usaha seperti transportasi, pemandu wisata, rumah makan, penginapan dan lain-lain.

Banyaknya aspek yang mencakup dunia kepariwisataan ini harus diimbangi dengan pengawasan dan penegakan hukum yang seimbang, karena, jika terjadi ketidak teraturan dan ketidakseimbangan maka persaingan yang tidak sehat akan terus berkembang dan dalam jangka pendek akan berdampak langsung pada 3 pemain utama dalam industri pariwisata (Spillane 1994 : 30), yaitu pada wisatawan sebagai konsumen dan masyarakat yang menjadi alat pariwisata dan dalam jangka panjang dapat berdampak pada bisnis pariwisata itu sendiri dan dapat mengakibatkan “Tourism kills tourism”, dimana satu golongan atau jenis usaha pariwisata akan merugikan bahkan mematikan golongan atau jenis usaha pariwisata lainnya.

Beberapa hal sudah menjadi masalah persaingan tidak sehat dalam kepariwisataan di Bali, seperti yang diutarakan oleh Ida Bagus Ngurah Wijaya, Ketua Gabungan Industri Pariwisata Indonesia wilayah Bali dalam sebuah media online kabar24.bisnis.com, pada tanggal 23 April 2013 adalah sebagai berikut,

"Pariwisata di Bali sudah mengalami masalah yang cukup serius akibat belum adanya pengaturan dari pemerintah. Belum ada klasterisasi wilayah serta pengaturan yang mengikat pengusaha dalam menjalankan bisnis wisatanya, dimana banyak pihak hotel yang mulai mengubah pola bisnisnya dengan mengakomodasi kepentingan wisatawan untuk traveling. Hotel banyak menjalankan paket perjalanan lengkap dengan hotel yang lazim menjadi market Travel Agent. Padahal hotel sudah jelas porsinya, yang berhak jual paket tour itu travel agent. Bahkan, Asita sebagai organisasi yang mewadahi Travel Agent, pernah menemui pihak hotel yang ikut menjual paket tour tersebut. Selain turunnya okupansi akibat banyaknya hotel, tumpang tindih pola usaha dan berebut wisatawan ini lebih diakibatkan karena belum adanya regulasi yang jelas dari pemerintah". 5

\footnotetext{
${ }^{5}$ Ashari Purwo Adi N, Inilah Problematika Bisnis Pariwisata di Pulau Dewata, http://kabar24.bisnis.com/read/20130423/78/10382/wisata-bali-inilah-problematika-bisnis-pariwisata-di-pulau-dewata, diakses 1 Februari 2018, pukul 20.00 wib.
} 
Menyikapi situasi dan kondisi seperti ini, sebagai regulator dan stabilisator, pemerintah berkepentingan untuk melakukan pengaturan serta pengawasan sektor industri pariwisata secara seimbang dan berkelanjutan, dengan melakukan penegakan hukum atas aturan yang berlaku di dunia kepariwisataan. Hal ini sesuai seperti yang dikatakan oleh Dekan Fakultas Hukum Universitas Udayana Prof. Drs. I Gusti Ngurah Wairocana bahwa salah satu faktor yang penting untuk ditata dalam masalah tourisme adalah masalah hukumnya, karena aspek pariwisata itu sangat amat luas, masalah itu akan berkembang dengan baik bilamana ada kepastian hukum. ${ }^{6}$ Oleh karena itu diperlukan aturan, pengawasan serta kebijakan-kebijakan yang membuat semua elemen kepariwisataan dapat berjalan sinergis.

Saat melakukan pengumpulan data pada bulan Februari hingga Juli 2018, diperoleh informasi dari Bapak I Ketut Ardana, ketua ASITA Bali bahwa, ternyata masalah "Hotel yang menjalankan paket perjalanan wisata" ini masih menjadi dilema berkepanjangan karena hingga saat ini masih terus terjadi. Bahkan ternyata hal tersebut, juga dilakukan oleh pelaku usaha penyedia akomodasi lainnya seperti Losmen, “Villa”. Artinya, sejak masalah ini sudah diutarakan oleh Ida Bagus Ngurah Wijaya pada tanggal 23 April 2013, masalah ini terus berlangsung, tanpa ada gugatan dari pihak yang di rugikan maupun tidak ada penertiban dari pihak yang berwenang, sehingga ditemukan hipotesa bahwa, ada kekosongan hukum, pembiaran ataupun tidak berjalannya pengawasan dalam dunia usaha pariwisata.

\section{KERANGKA TEORI.}

Dalam penelitian ini digunakan teori- teori yang bertujuan untuk meninjau dan menganalisis permasalahan yang ada, teori-teori tersebut adalah :

\section{A. Grand Theory: Teori Sistem Hukum Friedman.}

Dalam penerapan hukum, Lawrence M. Friedman mengemukakan bahwa efektifitas serta berhasil tidaknya penegakan dan kepastian hukum di suatu negara tergantung atas tiga unsur sistem hukum, yakni struktur hukum (structure of law), substansi hukum (substance of the law) dan budaya hukum (legal culture). ${ }^{7}$ Struktur hukum menyangkut komponen organ/ aparat penegak hukum, baik yang membuat peraturan maupun yang menerapkan atau melaksanakan peraturan, substansi hukum meliputi perangkat perundang-undangan dan atau produk hukum sedangkan budaya hukum merupakan nilai, norma ataupun hukum yang hidup (living law) dan dianut dalam suatu kehidupan

\footnotetext{
${ }^{6}$ (SB-Lik), ALSA seminarkan masalah hukum Pariwisata,http://suluhbali.co/alsa-seminarkan-masalah-hukumpariwisata/, diakses 18 Februari 2018, pukul 20.00 wib.

${ }^{7}$ Lawrence M. Friedman, Sistem Hukum ; Perspektif Ilmu Sosial (The Legal System ; A Social Science Perspective), Bandung: Nusa Media, 2009, hlm. 33.
} 
masyarakat. Dengan melihat pengertian dari teori M.Friedmen tersebut, kita dapat menarik kesimpulan bahwasannya ketiga unsur hukum itu harus berjalan bersama agar hukum yang di buat untuk menegakan keadilan itu dapat berjalan efektif, sehingga keadilan dapat di rasakan oleh masyarakat yang di atur oleh hukum itu sendiri.

B. Middle Theory: Teori Legitimasi Dan Validitas Hukum.

Teori validitas hukum merupakan salah satu teori yang penting dalam ilmu hukum. Teori validitas atau legitimasi dari hukum (legal validity) adalah teori yang mengajarkan bagaimana dan apa syarat-syaratnya agar suatu kaidah hukum menjadi legitimate dan sah (valid) berlakunya, sehingga dapat diberlakukan kepada masyarakat, bila perlu dengan upaya paksa, yakni suatu kaidah hukum yang memenuhi persyaratan-persyaratan sebagai berikut ${ }^{8}$ :

a. Kaidah hukum tersebut haruslah dirumuskan ke dalam herbagai bentuk aturan formal, seperti dalam bentuk pasal-pasal dari Undang-Undang Dasar, undang-undang dan berbagai bentuk peraturan lainnya, aturan-aturan internasional seperti dalam bentuk traktat, konvensi, atau setidaknya dalam bentuk adat kebiasaan.

b. Aturan formal tersebut harus dibuat secara sah, misalnya jika dalam bentuk undangundang harus dibuat oleh parlemen (bersama dengan pemerintah).

c. Secara hukum, aturan hukum tersebut tidak mungkin dibatalkan.

d. Terhadap aturan formal tersebut tidak ada cacat-cacat yuridis lainnya. Misalnya tidak bertentangan dengan peraturan yang lebih tinggi.

e. Kaidah hukum tersebut harus dapat diterapkan oleh badan-badan penerap hukum, seperti pengadilan, kepolisian, kejaksaan.

f. Kaidah hukum tersebut harus dapat diterima dan dipatuhi aleh masyarakat.

g. Kaidah hukum tersebut haruslah sesuai dengan jiwa bangsa yang bersangkutan.

Dengan demikian, maka "suatu kaidah hukum tidak dapat ditukar dengan kaidah moral atau kaidah politik. Dalam hal ini berarti bahwa validitas suatu aturan hukum tidak goyah hanya karena tidak bersesuaian dengan kaidah moral, kaidah politik atau kaidah ekonomi. Karena masing-masing bidang tersebut mengatur hal tersebut mengatu hal yang berbeda-beda meskipun dalam hal tertentu saling overlapping."9

C. Applied Theory: Asas Penegakan Hukum dan Kepastian Hukum.

Menurut Satjipto Rahardjo, "penegakan hukum diartikan sebagai suatu proses untuk mewujudkan keinginan-keinginan hukum, yaitu pikiran-pikiran dari badan-badan pembuat undangundang yang dirumuskan dan ditetapkan dalam peraturan-peraturan hukum yang kemudian menjadi kenyataan."10

\footnotetext{
${ }^{8}$ Munir Fuady, Teori-Teori Besar (Grand Teori) Dalam Hukum, Jakarta : Kencana, 2013, hlm. 109-110.

${ }^{9}$ Ibid.

${ }^{10}$ Satjipto Rahardjo, Masalah Penegakan Hukum, Bandung, Sinar Baru, 1983, hlm. 24
} 
Dalam Penegakan hukum harus ada Kepastian Hukum, dimana kepastian adalah perihal situasi, keadaan yang pasti, ketentuan atau ketetapannya. Hukum tanpa nilai kepastian akan kehilangan jati diri serta maknanya karena kepastian sendiri hakikatnya merupakan tujuan utama dari hukum. Kepastian hukum secara normatif adalah ketika suatu peraturan dibuat dan diundangkan secara pasti karena mengatur secara jelas dan logis. Jelas dalam artian tidak menimbulkan keragu-raguan, tidak berbenturan dengan norma serta konsisten dan konsekwen dimana dalam pelaksanaanya tidak dapat dipengaruhi oleh hal yang bersifat subyektif. Asas Kepastian Hukum harus dapat memberikan manfaat dan perlindungan yang seimbang bagi semua pihak.

\section{METODE PENELITIAN.}

\subsection{Jenis \& Sifat Penelitian}

Dalam menentukan jenis dan sifat penelitian ini, penulis menggunakan jenis penelitian metode yuridis normative atau penelitian doktrinal, yaitu penelitian dengan mengolah data yang diperoleh baik dari buku, jurnal, dan peraturan perundang-undangan yang ada serta putusan pengadilan, guna menyelesaikan sebuah permasalahan hukum.

\subsection{Pendekatan Penelitian}

Pendekatan yakni pendekatan yang digunakan dalam penelitian ialah antara lain: pendekatan perundang-undangan, pendekatan kasus, pendekatan historis, pendekatan perbandingan dan konseptual bisa satu pendekatan saja atau gabungan beberapa pendekatan tergantung bentuk dan sifat masalah (isu hukum) penelitian yang ingin dipecahkan. ${ }^{11}$

\subsection{Sumber Data}

1. Bahan Hukum Primer yaitu bahan-bahan hukum yang isinya mempunyai kekuatan mengikat kepada masyarakat, antara lain norma dasar, peraturan dasar, peraturan perundangundangan, yurisprudensi, traktat dan lain-lain. ${ }^{12}$ Dalam penelitian ini bahan hukum primer yang digunakan terdiri dari :

a. Peraturan Pemerintah Nomor 67 Tahun 1996 tentang Penyelenggaraan Kepariwisataan.

b. Keputusan Menteri Pariwisata, Pos dan Telekomunikasi Nomor KM.105/PW.304/MPPT91 tentang Usaha Jasa Pariwisata.

\footnotetext{
${ }^{11}$ FH-Ubhara Press, Pedoman Teknis Penulisan Tugas Akhir Universitas Bhayangkara, Jakarta: Fakultas Hukum, 2017, hlm 12 .

${ }^{12}$ Ronny Hanitijo Soemitro, Metodologi Penelitian Hukumdan Jurimetri, Jakarta, Ghalia Indonesia, 1990, hlm. 10
} 
c. Keputusan Menteri Pariwisata, Pos dan Telekomunikasi Nomor KM.10/HK/PM.102/MPPT-93 tentang Ketentuan Usaha Jasa Biro Perjalanan Wisata dan Agen Wisata.

d. Peraturan Menteri Kebudayaan dan Pariwisata Nomor PM.85/HK.501/MKP/2010 tentang Tata Cara Pendaftaran Usaha Jasa Perjalanan Wisata.

e. Undang-Undang Republik Indonesia Nomor. 10 Tahun 2009 tentang Kepariwisataan.

2. Bahan Hukum Sekunder yaitu bahan hukum yang memberikan penjelasan mengenai bahan hukum primer yang terdiri dari hasil penelitian, buku-buku, jurnal Ilmiah dan sebagainya. Bahan hukum sekunder ini bersifat sebagai pendukung, dalam arti untuk menunjang validitas dan reliabilitas data premier.

3. Bahan Hukum Tersier yaitu bahan hukum yang memberikan petunjuk maupun penjelasan terhadap bahan hukum primer dan sekunder seperti kamus hukum, ensiklopedia, internet dan sebagainya.

\subsection{Teknik Pengumpulan Data}

Teknik pengumpulan data yang digunakan dalam dalam penelitian ini adalah studi kepustakaan. Menurut Sugiyono, studi kepustakaan berkaitan dengan kajian teoritis dan referensi lain yang berkaitan dengan nilai, budaya dan norma yang berkembang pada situasi sosial yang diteliti, selain itu studi kepustakaan sangat penting dalam melakukan penelitian, hal ini dikarenakan penelitian tidak akan lepas dari literatur-literatur ilmiah. ${ }^{13}$

\subsection{Analisis Data}

Adapun analisis data yang digunakan dalam penelitian ini adalah analisis kualitatif, mengelolah data, menganalisa dan kemudian dituangkan dengan cara menggunakan kalimat.

\section{HASIL DAN PEMBAHASAN.}

Ketika mengkaji dan menganalisis masalah "Hotel dan penyedia akomodasi lainnya yang menjalankan usaha paket wisata perjalanan" ini, di sadari bahwa kondisi ini berdampak negatif bagi dunia usaha kepariwisataan di Bali baik dalam jangka pendek maupun jangka panjang, karena apa yang dilakukan pihak hotel dan penyedia akomodasi lainnya tersebut sudah melanggar batasan lingkup kegiatan usaha dan bertentangan dengan beberapa ketentuan yang berlaku yang diatur dalam Undang-Undang Republik Indonesia Nomor 10 Tahun 2009 Tentang Kepariwisataan dan Peraturan

${ }^{13}$ Sugiyono, Metode Penelitian Kuantitatif Kualitatif dan R\&D, Bandung: Alfabeta, 2012, hlm 38 
Pemerintah Republik Indonesia Nomor 67 Tahun 1996 Tentang Penyelengaraan Kepariwisataan sebagai berikut ${ }^{14}$ :

1. Undang-Undang Republik Indonesia Nomor 10 Tahun 2009 Tentang Kepariwisataan :

Pasal 14, ayat (1), huruf D dan F.

Usaha pariwisata meliputi, antara lain:

d. jasa perjalanan wisata; f. penyediaan akomodasi;

Penjelasannya sebagai berikut.

Huruf d.

Yang dimaksud dengan "usaha jasa perjalanan wisata" adalah usaha biro perjalanan wisata dan usaha agen perjalanan wisata. Usaha biro perjalanan wisata meliputi usaha penyediaan jasa perencanaan perjalanan dan/atau jasa pelayanan dan penyelenggaraan pariwisata, termasuk penyelenggaraan perjalanan ibadah. Usaha agen perjalanan wisata meliputi usaha jasa pemesanan sarana, seperti pemesanan tiket dan pemesanan akomodasi serta pengurusan dokumen perjalanan.

Huruf f.

Yang dimaksud dengan "usaha penyediaan akomodasi" adalah usaha yang menyediakan pelayanan penginapan yang dapat dilengkapi dengan pelayanan pariwisata lainnya. Usaha penyediaan akomodasi dapat berupa hotel, villa, pondok wisata, bumi perkemahan, persinggahan karavan, dan akomodasi lainnya yang digunakan untuk tujuan pariwisata.

Pasal 26 huruf $\mathrm{M}$ dan $\mathrm{N}$ yaitu :

Setiap pengusaha pariwisata berkewajiban:

m. menjaga citra negara dan bangsa Indonesia melalui kegiatan usaha kepariwisataan secara bertanggung jawab; dan n. menerapkan standar usaha dan standar kompetensi sesuai dengan ketentuan peraturan perundang-undangan.

2. Sedangkan dalam Peraturan Pemerintah Republik Indonesia Nomor 67 Tahun 1996 Tentang Penyelengaraan Kepariwisataan dapat ditemukan dalam beberapa pasal sebagai berikut :

Pasal 9, ayat (1) dan (2).

(1) Kegiatan usaha Biro Perjalanan Wisata meliputi jasa:

a. perencanaan dan pengemasan komponen-komponen perjalanan wisata, yang meliputi sarana wisata, obyek dan daya tarik wisata dan jasa pariwisata lainnya terutama yang terdapat di wilayah Indonesia, dalam bentuk paket wisata;

\footnotetext{
${ }^{14}$ Lihat ketentuan pasal 14, pasal 26 huruf M Undang-Undang Republik Indonesia Nomor 10 Tahun 2009 Tentang Kepariwisataan dan pasal 9, pasal 12, pasal 58, pasal 59, pasal 60, pasal 61 Peraturan Pemerintah Republik Indonesia Nomor 67 Tahun 1996 Tentang Penyelengaraan Kepariwisataan
} 
b. penyelenggaraan dan penjualan paket wisata dengan cara menyalurkan melalui Agen Perjalanan wisata dan atau menjualnya langsung kepada wisatawan atau konsumen;

c. penyediaan layanan pramuwisata yang berhubungan dengan paket wisata yang dijual;

d. penyediaan layanan angkutan wisata;

e. penyediaan akomodasi, restoran, tempat konvensi, dan tiket pertunjukan seni budaya serta kunjungan ke obyek dan daya tarik wisata;

f. pengurusan dokumen perjalanan, berupa paspor dan visa atau dokumen lain yang dipersamakan;

g. penyelenggaraan perjalanan ibadah agama; dan

h. penyelenggaraan perjalanan insentif.

(2) Kegiatan usaha sebagaimana dimaksud dalam ayat (1) huruf a, huruf b, dan huruf c merupakan kegiatan pokok yang wajib diselenggarakan oleh Biro Perjalanan wisata.

Penjelasannya ;

Ayat (1) Huruf a,

Produk utama usaha biro perjalanan wisata adalah berbagai jenis paket perjalanan wisata dan pengaturan kemudahan bagi yang akan melakukan perjalanan. Dalam hal ini, Biro Perjalanan Wisata bertindak sebagai produsen dan bertanggung jawab atas paket wisata yang dijualnya.

Huruf $b$

Penjualan paket wisata kepada konsumen (wisatawan) dapat dilakukan secara langsung atau melalui agen Perjalanan Wisata. Dalam hal paket wisata dijual melalui Agen Perjalanan Wisata, tanggung jawab atas pemenuhan komponen dalam paket wisata tetap berada pada Biro Perjalanan Wisata.

Pasal 58,

Usaha Penyediaan Akomodasi

Usaha penyediaan akomodasi dapat berupa:

a. usaha hotel;

b. usaha pondok wisata;

c. usaha bumi perkemahan; dan

d. usaha persinggahan, karavan.

Penjelasannya :

Huruf a.

Termasuk dalam usaha hotel adalah pengusahaan hotel bintang,hotel melati, dan penginapan remaja. 
Pasal 61,

(1) Kegiatan usaha hotel meliputi:

a. penyediaan kamar tempat menginap;

b. penyediaan tempat dan pelayanan makan dan minum;

c. pelayanan pencucian pakaian/binatu;

d. penyediaan fasilitas akomodasi dan pelayanan lain, yang diperlukan bagi penyelenggaraan kegiatan usaha hotel.

(2) Kegiatan sebagaimana dimaksud dalam ayat (1) huruf a merupakan pelayanan pokok yang harus disediakan usaha hotel.

(3) Menteri menetapkan penggolongan kelas hotel sesuai dengan jenis fasilitas akomodasi dan pelayanan yang disediakan.

Dapat dilihat dalam pasal-pasal tersebut diatas bahwa, usaha "paket perjalanan wisata' merupakan lingkup kegiatan usaha Biro Perjalanan Wisata dan tidak termasuk dalam lingkup kegiatan usaha perhotelan. Sehingga kondisi tersebut merupakan peristiwa hukum dan jelas terjadi perbuatan yang salah dalam bentuk pelanggaran perizinan lingkup kegiatan usaha yang termasuk dalam Perbuatan Melawan Hukum yang dilakukan oleh pihak hotel yang dapat mengakibatkan kerugian bagi usaha Biro ataupun Agen perjalanan wisata.

Perlu dipahami dan disadari bersama oleh para pelaku usaha kepariwisataan, Perbuatan Melawan Hukum ini merupakan tindakan yang dilarang dan melanggar hukum yang jika pelaku terbukti melakukan pelanggaran perijinan ataupun aturan perundang- undangan yang berlaku dan mengakibatkan kerugian bagi pihak lain maka pihak yang dirugikan berhak untuk mengajukan gugatan secara perdata yang disertai tuntutan ganti rugi pada pihak yang melakukan Perbuatan Melawan Hukum tersebut.

Mengenai Perbuatan Melawan Hukum ini diatur dalam Pasal 1365 Kitab Undang-Undang Hukum Perdata (KUHPerdata), berbunyi: “Tiap perbuatan yang melanggar hukum dan membawa kerugian kepada orang lain, mewajibkan orang yang menimbulkan kerugian itu karena kesalahannya untuk menggantikan kerugian tersebut."

Unsur-unsur Perbuatan Melawan Hukum sendiri adalah sebagai berikut:

1. Adanya perbuatan melawan hukum;

2. Adanya kesalahan;

3. Adanya kerugian.

4. Adanya hubungan Kausalitas atau sebab akibat antara kerugian dan perbuatan; 
Jika dianalisis hubungan unsur Perbuatan Melawan Hukum dengan permasalahan yang dikemukan diatas yaitu, Perbuatan Melawan Hukum oleh pihak Hotel dan penyedia akomodasi lainnya terkait menjalankan paket wisata perjalanan yang lazimnya di jalankan oleh Biro Perjalanan Wisata maka dapat di kemukakan sebagai berikut :

I. Unsur adanya perbuatan melawan hukum

Perbuatan melawan hukum berarti adanya perbuatan atau tindakan dari pelaku yang melanggar/melawan hukum.

Pada saat pihak hotel dengan sengaja melakukan inovasi usaha dengan menjalankan "paket wisata perjalanan" yang sudah jelas tidak termasuk dalam lingkup usaha dan tidak termasuk dalam perizinan yang diberikan bagi pihak Hotel, maka pada saat itu pula pihak hotel sudah melawan/melanggar hukum. Apalagi jika pihak hotel sudah mengetahui dan menyadari bahwa usaha "paket wisata perjalanan" tidak termasuk dalam lingkup kegiatan usaha perhotelan dan lazimnya serta sepatutnya dijalankan oleh pihak Biro Perjalanan Wisata.

Perbuatan Melawan Hukum ditafsirkan secara sempit, yaitu hanya terhadap hukum yang tertulis saja, yaitu undang-undang dan aturan tertulis lainnya. Jadi seseorang atau badan hukum hanya dapat digugat apabila melanggar hukum tertulis saja. Namun lembaga pengadilan Indonesia memiliki rujukan Yurisprudensi yang memperluas pengertian melanggar/melawan hukum, yaitu putusan Mahkamah Agung Belanda pada tahun 1919 dalam kasus Arrest Cohen-Lindenbaum (H.R. 31 Januari 1919). Yurisprudensi tersebut kemudian telah memperluas pengertian melawan/melanggar hukum tidak hanya terbatas pada undang-undang (hukum tertulis saja) tapi juga hukum yang tidak tertulis, sebagai berikut: ${ }^{15}$

1. Melanggar Undang-Undang, yang artinya perbuatan yang dilakukan jelas-jelas melanggar undang-undang/ aturan/ perizinan yang berlaku.

2. Melanggar hak subjektif orang lain, artinya jika perbuatan yang dilakukan telah melanggar hak-hak orang lain/subyek hukum lain yang dijamin oleh hukum (termasuk tapi tidak terbatas pada hak yang bersifat pribadi, kebebasan, hak kebendaan, kehormatan, nama baik ataupun hak perorangan/hak badan hukum lainnya.

3. Bertentangan dengan kewajiban hukum si pelaku, artinya kewajiban hukum baik yang tertulis maupun yang tidak tertulis, termasuk hukum publik, perizinan, lingkup kegiatan usaha.

\footnotetext{
${ }^{15} \mathrm{http}: / / w w w . h u k u m o n l i n e . c o m / b e r i t a / b a c a / h o l 3616 /$ perbuatan-melawan-hukum-dan-wanprestasi-sebagai-dasar-gugatan, diakses 18 Juni 2018, pukul 20.00 wib.
} 
4. Bertentangan dengan kesusilaan, yaitu kaidah moral ( Pasal 1335 KUH Perdata "suatu perjanjian tanpa sebab, atau yang telah dibuat karena sesuatu sebab yang palsu atau terlarang, tidak mempunyai kekuatan" Junto Pasal 1337 KUH Perdata “suatu sebab adalah terlarang, apabila dilarang oleh undang-undang, atau apabila berlawanan dengan kesusilaan baik atau ketertiban umum ") .

5. Bertentangan dengan sikap kehati-hatian yang sepatutnya dalam masyarakat.

Kriteria ini bersumber pada hukum tak tertulis (bersifat relative), yaitu perbuatan yang dilakukan bertentangan dengan sikap yang baik/kepatutan dalam masyarakat untuk memperhatikan kepentingan orang lain.

Terkait dengan masalah yang dikemukakan di atas, dapat dipahami bahwa pihak hotel yang menjalankan usaha paket perjalanan wisata yang lazimnya dijalankan oleh Biro perjalanan wisata telah melakukan perbuatan yang bertentangan dengan aturan dan perizinan yang berlaku dan melanggar hak subyek hukum lain, melanggar sikap kepatutan dan dapat mengganggu keseimbangan usaha kepariwisataan sesuai dengan asas keseimbangan kehidupan yang terkandung dalam "Tri Hita Kerana" yang menjadi falsafah dan adat istiadat masyarakat Bali sejak dulu hingga sekarang.

\section{Unsur adanya kesalahan}

Pada prakteknya dalam dunia usaha, penyebab unsur adanya kesalahan ini ada 2 (dua), bisa karena kesengajaan atau karena kealpaan. Kesengajaan maksudnya ada kesadaran yang oleh orang normal pasti tahu konsekuensi dari perbuatannya itu akan merugikan orang lain.

Sedangkan Kealpaan berarti ada perbuatan mengabaikan sesuatu yang mestinya dilakukan, atau tidak berhati-hati atau teliti sehingga menimbulkan kerugian bagi orang lain. ${ }^{16}$

Namun demikian adakalanya suatu keadaan tertentu dapat meniadakan unsur kesalahan, misalnya dalam hal keadaan memaksa (overmacht) atau si pelaku tidak sehat pikirannya (gila)

Terkait dengan permasalah yang dikemukakan diatas, keadaan memaksa (overmacht) maupun pelaku tidak sehat pikirannya (gila) dapat dikesampingkan. Karena hampir tidak mungkin itu terjadi pada pelaku usaha perhotelan yang masih aktif berinovasi. Sedangkan unsur Kesengajaan maupun Kealpaan sangat mungkin terjadi dan dilakukan oleh pelaku usaha perhotelan yang melakukan inovasi dengan menjalankan usaha "paket perjalanan wisata" yang lazimnya dilakukan oleh Biro Perjalanan Wisata. Artinya, yang pertama yaitu pelaku usaha perhotelan dengan sengaja dan tahu perbuatannya akan merugikan pihak biro perjalaan wisata, namun tetap melakukan

\footnotetext{
${ }^{16}$ Munir Fuady, Perbuatan Melawan Hukum: Pendekatan Kontemporer, Bandung : PT. Citra Aditya Bakti, 2002 hal.73.
} 
perbuatan tersebut. Kemudian yang kedua, pelaku usaha perhotelan mengabaikan atau tidak berhatihati atau teliti sehingga inovasi usaha yang dilakukan merugikan pihak Biro Perjalanan Wisata.

III. Unsur adanya hubungan sebab akibat antara kerugian dan perbuatan (Hubungan Kausalitas).

Maksud dari unsur ini adalah, adanya hubungan sebab akibat secara langsung antara perbuatan yang dilakukan dengan akibat/kerugian yang muncul, dengan kata lain kerugian yang terjadi disebabkan perbuatan si pelaku atau kerugian tidak akan terjadi jika pelaku tidak melakukan perbuatan melawan hukum tersebut.

Terkait permasalahan diatas, apabila terbukti adanya kerugian yang dialami oleh pihak Biro Perjalanan Wisata akibat perbuatan pihak perhotelan yang menjalan usaha "paket perjalanan wisata", maka unsur ini terpenuhi.

Sebagaimana tertulis diatas "Bahkan, Asita sebagai oraganisasi yang mewadahi Travel Agent, pernah menemui pihak hotel yang ikut menjual paket tour tersebut". Hal ini tentunya dapat dipahami di akibatkan karena adanya kerugian bagi pihak Biro Perjalanan Wisata yang diakibatkan karena pihak hotel menjalankan usaha "paket perjalanan wisata" tersebut.

\section{Unsur adanya kerugian}

Akibat perbuatan pelaku menimbulkan kerugian. Terkait permasalahan yang dikemukakan diatas, dapat kita pahami bahwa akibat perbuatan pihak hotel yang menjalankan usaha "paket perjalanan wisata" tersebut berpotensi menimbulkan kerugian bagi pihak Biro Perjalanan Wisata baik secara langsung maupun tidak langsung. Kerugian yang dimaksud di sini dibagi jadi 2 (dua) yaitu Materil dan Imateril. Kerugian Materil misalnya kerugian karena pihak hotel menjalankan usaha "paket perjalanan wisata", maka berakibat berkurangnya konsumen ataupun hilangnya keuntungan yang seharusnya dapat diperoleh oleh pihak Biro Perjalanan Wisata, berikut pula kerugian atas biaya pemasaran maupun operasiona yang telah dikeluarkan oleh pihak Biro Perjalanan Wisata terkait dengan paket yang sama yang dijalankan oleh pihak hotel.

Kerugian Imateril misalnya kekecewaan, sakit, dan kehilangan motivasi usaha maupun proyeksi peluang usaha yang pada prakteknya akan dinilai dalam bentuk nominal/ uang.

Adapun pemberian ganti kerugian menurut KUHPerdata sebagai berikut ${ }^{17}$ :

1. Ganti rugi untuk semua perbuatan melawan hukum (Pasal 1365 KUHPerdata);

${ }^{17}$ Ibid, hal. 137 
2. Ganti rugi untuk perbuatan yang dilakukan oleh orang lain (Pasal 1367 KUHPerdata). Pasal 1367 ayat (1) KUHPerdata, seseorang tidak hanya bertanggungjawab atas kerugian yang disebabkan perbuatannya sendiri, melainkan juga atas kerugian yang disebabkan perbuatan orangorang yang menjadi tanggungannya atau disebabkan barang-barang yang berada dalam pengawasannya ( vicarious liability).

3. Ganti rugi untuk pemilik binatang ( Pasal 1368 KUHPerdata ).

4. Ganti rugi untuk pemilik gedung yang ambruk ( Pasal 1369 KUHPerdata ).

5. Ganti rugi untuk keluarga yang ditinggalkan oleh orang yang dibunuh ( Pasal 1370 KUHPerdata ).

6. Ganti rugi karena telah luka tau cacat anggota badan (Pasal 1371 KUHPerdata).

7. Ganti rugi karena tindakan penghinaan (Pasal 1372 KUHPerdata)

Terkait dengan permasalah diatas, KUHPerdata tidak mengatur secara spesifik mengenai ganti kerugian yang harus dibayar karena Perbuatan Melawan Hukum sedang Pasal 1243 KUHPerdata membuat ketentuan tentang ganti rugi karena Wanprestasi. Namun menurut Yurisprudensi yang menjadi rujukan, ketentuan ganti kerugian karena wanprestasi dapat diterapkan untuk menentukan ganti kerugian karena Perbuatan Melawan Hukum. ${ }^{18}$ Yurisprudensi atas putusan Perbuatan Melawan Hukum dengan ganti kerugian dapat kita rujuk dari beberapa contoh putusan perkara terkait beberapa hotel di Bali yang digugat dengan pasal Perbuatan Melawan Hukum ( pasal 1365 KUH Perdata Indonesia ) oleh PT. ISM dan PT. Nonbar karena dianggap telah melanggar Undang-undang Hak Cipta dengan menayangkan dan mengadakan kegiatan acara Nonton Bareng Siaran Piala Dunia tahun 2014. Gugatan perkara tersebut melibatkan banyak hotel dan tempat hiburan di Bali dan beberapa perkara sudah memperoleh keputusan tetap dan beberapa perkara masih terus berlanjut baik di persidangan maupun dalam proses negosiasi ${ }^{19}$.

Sanksi yang keras tersebut bertujuan agar pelaku tidak lagi melakukan perbuatan yang sama dan menjadi pembelajaran bagi masyarakat ataupun pelaku usaha lainnya agar tidak melakukan Perbuatan Melawan Hukum lainnya.

\footnotetext{
${ }^{18}$ M.A Moegni Djojodirdjo: Perbuatan Melawan Hukum, Jakarta: Pradnya Paramita, 1982, hal 73. Ditambahkan dengan R. Wirjono Prodjodikoro: Perbuatan Melawan Hukum, Bandung: Sumur Bandung, 1984, hal 44. Kitab Undang-Undang Hukum Perdata tidak membedakan dua macam kerugian, sehingga Pasal 1246 KUHPerdata dapat diterapkan terhadap perbuatan melawan hukum atau wanprestasi.

${ }^{19} \mathrm{http}: / /$ balitribune.co.id/content/sembilan-hotel-di-bali-digugat-ke-pn-surabaya, diakses hari Selasa, $10 \mathrm{Juli} 2018$, pukul. 13.00 wib.
} 
Perlu di ketahui bersama, selain UU dan PP tentang Kepariwisataan, terdapat juga ketentuan-ketentuan yang mengatur mengenai "Definisi Usaha dan Klasifikasi Baku Lapangan Usaha Indonesia" untuk bidang Perhotelan dan Biro Perjalanan Wisata yang menyatakan bahwa, berdasarkan pasal 1 angka 27 Permenpar 18/2016, yang dimaksud dengan usaha penyediaan akomodasi adalah usaha penyediaan pelayanan penginapan untuk wisatawan yang dapat dilengkapi dengan pelayanan pariwisata lainnya sedangkan definisi usaha Perhotelan menurut Pasal 1 angka 28 Permenpar 18/2016 adalah usaha penyediaan akomodasi secara harian berupa kamar-kamar di dalam 1 (satu) atau lebih bangunan, termasuk losmen, penginapan, pesanggrahan, yang dapat dilengkapi dengan jasa pelayanan makan dan minum, kegiatan hiburan dan/atau fasilitas lainnya. Berdasarkan definisi tersebut, usaha hotel merupakan salah satu bidang usaha penyediaan akomodasi, hal ini dinyatakan dalam pasal 11 huruf a Permenpar 18/2016.

Kemudian, cakupan usaha hotel yang ditentukan oleh Klasifikasi Baku Lapangan Usaha Indonesia (KBLI) yang dikeluarkan dalam Peraturan Kepala Badan Pusat Statistik Republik Indonesia Nomor. 95 Tahun 2015 Tentang Klasifikasi Baku Lapangan Usaha Indonesia dinyatakan sebagai berikut :

1. Penyediaan Akomodasi ( KBLI No. 55 ).

Golongan pokok ini mencakup penyediaan akomodasi jangka pendek untuk pengunjung dan pelancong lainnya. Termasuk penyediaan akomodasi yang lebih lama untuk pelajar, pekerja dan sejenisnya. Penyediaan akomodasi dapat hanya menyediakan fasilitas akomodasi saja atau fasilitas akomodasi dan fasilitas makanan dan minuman, atau fasilitas akomodasi, makanan dan minuman dan/atau fasilitas rekreasi.

2. Penyediaan Akomodasi Jangka Pendek ( KBLI No. 551).

Golongan ini mencakup penyediaan akomodasi, khususnya untuk harian atau mingguan, pada prinsipnya untuk tinggal dalam jangka pendek sebagai pengunjung. Termasuk penyediaan akomodasi dengan furnitur, lengkap dengan dapur, dengan atau tanpa jasa pramuwisma dan sering kali termasuk beberapa tambahan jasa dan fasilitas seperti fasilitas parkir, binatu, kolam renang, ruang olahraga, fasilitas rekreasi dan ruang rapat. Termasuk juga akomodasi yang disediakan oleh berbagai macam hotel, penginapan, losmen, hostel, villa dan lain-lain.

Dari penjabaran cakupan usaha perhotelan sebagai penyedia akomodasi tersebut diatas, ditemukan bahwa "paket perjalanan wisata" tidak termasuk dalam cakupan usaha perhotelan maupun penyedia akomodasi lainnya. 
Sementara terkait dengan Biro Perjalanan Wisata, menurut Surat Keputusan Direktur Jendral Pariwisata No.Kep.16/U/II/88 tanggal 25 Februari 1988 tentang Pelaksanaan Ketentuan Usaha Perjalanan, pada Bab I Penelitian Umum Pasal 1 Huruf b, yang dimaksud dengan Biro Perjalanan (travel agency) adalah kegiatan usaha yang bersifat komersial yang mengatur, menyediakan dan menyelenggarakan pelayanan bagi seseorang, sekelompok orang, untuk melakukan perjalanan dengan tujuan untuk berwisata dimana badan usaha ini menyelenggarakan kegiatan perjalanan yang bertindak sebagai perantara dalam menjual atau mengurus jasa untuk melakukan perjalanan baik di dalam negeri dan/atau ke luar negeri. ${ }^{20}$ Adapun Lingkup kegiatan usaha biro perjalanan (travel agency), dalam ketentuan Pasal 4 Bab II dijelaskan sebagai berikut :

a) Membuat, menjual dan menyelenggarakan paket wisata;

b) Mengurus dan melayani kebutuhan jasa angkutan bagi perorangan dan/atau kelompok orang yang diurusnya;

c) Melayani pemesanan akomodasi, restoran, dan sarana wisata lainnya;

d) Mengurus dokumen perjalanan;

e) Menyelenggarakan panduan perjalanan wisata;

f) Melayani penyelenggaraan konvensi.

Kemudian pada tahun 1993, dikeluarkan keputusan menteri pariwisata, pos, dan telekomuniksai Nomor KM.10/PW.102/MPPT93, yang menyatakan bahwa ; Biro perjalanan wisata adalah usaha yang merencanakan perjalanan wisata dan atau jasa pelayanan penyelenggaran wisata (pasal 1 ayat 1), dan agen per jalanan wisata adalah usaha jasa perantara untuk menjual atau meng urus jasa untuk perjalanan wisata (pasal 1 ayat 3). ${ }^{21}$ Adapun lingkup kegiatan dan penguasaan dari biro perjalanan wisata dan agen perjalanan wisata meliputi (pasal 2 ayat 1) :

- Penyusunan dan penyelenggaraan paket wisata;

- Penyediaan dan/atau pelayanan angkutan wisata;

- Pemesanan akomodasi, restoran dan sarana lainnya;

- Penyelengaraan pelayanan perlengkapan (dokumen) perjalanan wisata.

Selanjutnya, dalam melakukan kegiatan usahanya, Biro Perjalanan Wisata (BPW) dan Asosiasi Perjalanan Wisata (APW), berada di bawah naungan organisasi kepariwisataan yaitu ASITA (Association of the Indonesian Tours dan Travel Agencies), oleh karena itu peran ASITA dalam penyelenggaraan, pengawasan maupun pemeliharaan Pariwisata berkelanjutan sangat penting,

\footnotetext{
${ }^{20}$ Surat Keputusan Direktur Jendral Pariwisata No.Kep.16/U/II/88 tanggal 25 Februari 1988 tentang Pelaksanaan Ketentuan Usaha Perjalanan

${ }^{21}$ Keputusan menteri pariwisata, pos, dan telekomuniksai Nomor KM.10/PW.102/MPPT93
} 
karena konsep keseimbangan kehidupan pariwisata harus selalu di prioritaskan dalam pelaksanaan program-program paket perjalanan wisata yang ditawarkan oleh BPW maupun APW.

Sedangkan cakupan usaha Biro Perjalanan wisata yang ditentukan oleh Klasifikasi Baku Lapangan Usaha Indonesia (KBLI) adalah sebagai berikut:

1. Aktivitas Biro Perjalanan Wisata.

( KBLI No. 7912 ).

Sub golongan ini mencakup kegiatan penyusunan dan pengemasan tur yang dijual melalui agen perjalanan atau secara langsung oleh penyelenggara tur. Tur tersebut mungkin mencakup beberapa atau seluruh dari hal-hal berikut, seperti transportasi, akomodasi, makanan dan kunjungan ke museum, tempat sejarah atau budaya, teater, kegiatan musik atau olahraga.

2. Aktivitas Biro Perjalanan Wisata.

( KBLI No. 79120 ).

Kelompok ini mencakup usaha yang kegiatannya melakukan perencanaan dan pengemasan komponen-komponen perjalanan wisata termasuk wisata alam di kawasan hutan, yang meliputi sarana wisata, obyek dan daya tarik wisata dan jasa pariwisata lainnya terutama yang terdapat di wilayah Indonesia dalam bentuk paket wisata; melakukan penyelenggaraan dan penjualan paket wisata dengan cara menyalurkan melalui Agen Perjalanan dan atau menjualnya langsung kepada wisatawan atau konsumen; melakukan penyediaan layanan pramuwisata yang berhubungan dengan paket wisata yang dijual; melakukan penyediaan layanan angkutan wisata; melakukan pemesanan akomodasi, restoran, tempat konvensi dan tiket penjualan seni budaya serta kunjungan ke obyek dan daya tarik wisata; melakukan pengurusan dokumen perjalanan, berupa paspor dan visa atau dokumen lain yang dipersamakan, melakukan penyelenggaraan ibadah agama dan perjalanan insentif dan telah mendapatkan surat keputusan sebagai biro perjalanan wisata dari instansi yang membinanya.

Jika dianalisis sesuai rujukan aturan dan perundang-undangan, definisi, serta Klasifikasi Baku Lapangan Usaha Indonesia tersebut diatas, dapat dipahami dengan jelas bahwa 'paket perjalanan wisata" tidak termasuk dalam lingkup kegiatan usaha perhotelan dan penyedia akomodasi lainnya dan secara jelas, tegas dan sah merupakan lingkup bidang usaha Biro Pejalanan Wisata.

Apakah "Pihak hotel dan penyedia akomodasi lainnya yang menjalankan usaha paket perjalanan wisata" tersebut dilakukan atas dasar 'kesengajaan' atau "kealpaan”?

Apapun alasan atas dilakukannya perbuatan tersebut oleh pihak hotel dan penyedia akomodasi lainnya, penelitian ini menganalisis atas temuan adanya perisitwa hukum berupa Perbuatan Melawan Hukum yang dilakukan oleh pihak hotel terkait dengan melaksanakan usaha perjalanan paket wisata yang menurut aturan dan perundang-undangan yang berlaku seharusnya menjadi cakupan usaha Biro Perjalanan Wisata, dimana hal tersebut mengakibatkan kerugian langsung maupun tidak langsung bagi pelaku usaha Biro Perjalanan Wisata. 
Dengan demikian, pihak Biro Perjalanan Wisata dapat/ berhak mengajukan gugatan perdata atas Perbuatan Melawan Hukum yang dilakukan oleh pihak hotel dan penyedia akomodasi lainnya, disertai dengan tuntutan ganti rugi karena Perbuatan Melawan Hukum, baik atas kerugian materiil maupun immateriil.

Mencermati permasalahan tersebut, dunia usaha kepariwisataan Bali perlu ditata dengan aturan yang jelas dan bermanfaat serta penegakan hukum yang tegas agar seluruh bidang usaha dapat berjalan bersama dengan sinergis demi tercapainya keseimbangan kehidupan dunia usaha kepariwisataan yang sesuai dengan falsafah hidup masyarakat Bali yakni "Tri Hita Karana" , sehingga kepariwisataan yang berkelanjutan dapat terlaksana dengan baik dan benar.

\section{KESIMPULAN DAN SARAN.}

1. Terjadi peristiwa hukum berupa Perbuatan Melawan Hukum yang dilakukan oleh pihak Hotel dan penyedia akomodasi lainnya terkait menjalankan usaha "paket perjalanan wisata". Karena hal tersebut melanggar batasan lingkup usaha dan perizinan yang berlaku bagi jenis usaha perhotelan dan penyedia akomodasi lainnya dan hal tersebut mengakibatkan kerugian bagi pelaku usaha Biro Perjalanan Wisata.

2. Terjadinya Perbuatan Melawan Hukum dalam hal ini asas kepatutan yaitu adanya pelangaran Hukum Adat Bali yang dilakukan oleh pihak hotel terkait menjalankan usaha 'paket perjalanan wisata' yang lazimnya dijalankan oleh pihak Biro Perjalanan Wisata. Karena perbuatan tersebut melanggar falsafah hidup masyarakat Bali yaitu "keseimbangan kehidupan" yang terkandung dalam Tri Hita Karana.

3. Fenomena ini dapat terus berlangsung apabila tidak ada edukasi maupun sosialisasi Hukum Kepariwisataan bagi para pelaku usaha Perhotelan, Biro Perjalanan Wisata maupun usaha pariwisata lainnya, apalagi jika tidak ada pengawasan bahkan terjadi pembiaran oleh pihak yang berwenang, maka potensi Perbuatan Melawan Hukum yang mengakibatkan kerugian bagi pelaku usaha lainnya akan terus berlangsung.

4. Diperlukan adanya penegakan hukum yang tegas agar pelaku tidak lagi melakukan pelanggaran hukum, apalagi merugikan pihak lain dan agar menjadi pembelajaran bagi pelaku usaha lainnya maupun masyarakat.

5. Diperlukannya aturan, perencanaan, pembangunan dan pengawasan yang konsisten serta kebijakan-kebijakan Kepariwisataan yang membuat semua element kepariwisataan dapat berjalan sinergis dengan prinsip "Integrated One Island Management Communication" 
6. Diperlukan adanya sosialisasi yang efektif dan menyeluruh atas aturan-aturan yang terkait dengan semua golongan pelaku usaha kepariwisataan untuk mencegah terjadinya persaingan usaha yang tidak sehat.

7. Penerapan peraturan yang terkait pariwisata yang terintegrasi antara pemerintah daerah dengan pemerintah pusat secara konsisten dan berkesinambungan dengan penegakan hukum yang jelas dan tegas untuk menjaga keseimbangan kehidupan kepariwisataan Bali yang berdasarkan Tri Hita Karana.

8. Merubah mind set (pola pikir) pengembangan kepariwisataan dari quantity over quality tourism menjadi "Quantity and Quality Tourism” demi terlaksananya Kepariwisataan yang berkelanjutan. 


\section{DAFTAR PUSTAKA.}

\section{Buku.}

Munir Fuady, Perbuatan Melawan Hukum: Pendekatan Kontemporer, Bandung : PT. Citra Aditya Bakti, 2002 hal.73.

M.A Moegni Djojodirdjo: Perbuatan Melawan Hukum, Jakarta: Pradnya Paramita, 1982, hal 73.

R. Wirjono Prodjodikoro: Perbuatan Melawan Hukum, Bandung: Sumur Bandung, 1984, hal 44. Kitab Undang-Undang Hukum Perdata tidak membedakan dua macam kerugian, sehingga Pasal 1246 KUHPerdata dapat diterapkan terhadap perbuatan melawan hukum atau wanprestasi.

\section{Internet.}

Ashari Purwo Adi N, http://kabar24.bisnis.com/read/20130423/78/10382/wisata-bali-inilahproblematika-bisnis-pariwisata-di-pulau-dewata, diakses 1 Februari 2018, , pukul 20.00 wib.

https://beritabali.com/read/2016/03/30/201603300001/Pariwisata-Bali-Tak-Terkontrol-AkanTerjadi-Tourism-Kills-Tourism.html, diakses 17 Februari 2018, pukul. 20.30 wib.

http://balitribune.co.id/content/sembilan-hotel-di-bali-digugat-ke-pn-surabaya, diakses hari Selasa, 10 Juli 2018, pukul. 13.00 wib.

I Made Surya, PHRI : Jumlah hotel di Bali membludak,Shttps://bali.antaranews.com/berita/102794/phri-jumlah-hotel-di-bali-membludak, diakses 17 Februari 2018,pukul. 20.15 wib.

(SB-Lik), ALSA seminarkan masalah hukum Pariwisata,http://suluhbali.co/alsa-seminarkanmasalah-hukum-pariwisata/, diakses 18 Februari 2018, pukul 20.00 wib.

Prosentase tingkat hunian kamar hotel di Bali Th.2012 2017,http://www.disparda.baliprov.go.id/id/Statistik4, diakses 17 Februari 2018, pukul 15.30. wib.

http://www.hukumonline.com/berita/baca/hol3616/perbuatan-melawan-hukum-danwanprestasi-sebagai-dasar-gugatan, diakses 18 Juni 2018, pukul 20.00 wib.

Yayasan Bai Galang, http://www.babadbali.com/canangsari/trihitakarana.htm, diakses 15 Februari 2018, pukul 15.00. wib.

\section{Peraturan dan Undang - Undang.}

Ketentuan umum, Pasal 1 peraturan daerah provinsi Bali nomor 2 tahun 2012 tentang kepariwisataan budaya Bali. 
Ketentuan pasal 14, pasal 26 huruf M Undang-Undang Republik Indonesia Nomor 10 Tahun 2009 Tentang Kepariwisataan dan pasal 4, pasal 5, pasal 6, pasal 7, pasal 8, pasal 12, pasal 14, pasal 15,, pasal 58, pasal 61 Peraturan Pemerintah Republik Indonesia Nomor 67 Tahun 1996 Tentang Penyelengaraan Kepariwisataan.

Ketentuan umum, Pasal 1 peraturan daerah provinsi Bali nomor 2 tahun 2012 tentang kepariwisataan budaya Bali.

Keputusan menteri pariwisata, pos, dan telekomuniksai Nomor KM.10/PW.102/MPPT93.

Klasifikasi Baku Lapangan Usaha Indonesia (KBLI), Peraturan Kepala Badan Pusat Statistik Republik Indonesia Nomor. 95 Tahun 2015 Tentang Klasifikasi Baku Lapangan Usaha Indonesia.

Peraturan Menteri Pariwisata Nomor 18 Tahun 2016 tentang Pendaftaran Usaha Pariwisata. 